\title{
CONTROL RECONSTRUCTION OF THE HOMELESS CHILDREN AS THE IMPACT OF URBAN DEVELOPMENT IN LAW PERSPECTIVE \\ (A Study in Samarinda)
}

\author{
Isnawati \\ Faculty of Law, Tujuh Belas Agustus University, Samarinda \\ isnawati21kaltim@gmail.com
}

\begin{abstract}
Homeless children as a social issue, especially in urban society, in the view of experts and related the organization and departments do not have a uniform similarity of opinion or definition for that matter. In this context, homeless children are seen as a social Clearly a social problem that requires an Appropriate methods of settlement in accordance with the expectations of all stakeholders. The research method used a sociological Juridical approach by solving research problems using the data consisting of legal secondary materials or legal regulations used to implement the data to primary data. The results of the research are: 1) Factors that can influence the municipal government in tackling the problems of children who are above the social environmental factors, the Community Culture, the Migration Factor The three factors are the reality that can not be avoided by the city government that will cause the child homeless children in Samarinda City. 2) The legal Efforts undertaken by the municipality in a different context from the development undertaken by the Samarinda City Regulation No. 16 of 2002 are not yet applicable, with the improvement of the Samarinda City Regulation No. 7 of 2017 the which is implemented a development with the current realities.
\end{abstract}

Keywords: Reconstruction; Homeless Children; Law Perspective.

\section{A. INTRODUCTION}

Samarinda city is part of the territory of Indonesia, located on the island of Borneo and is the capital of East Kalimantan. Samarinda City administrative region consists of 10 districts and 53 villages. The population of the city of Samarinda as many as 901064 people, with an estimated population growth rate of 5 $7 \%$ per year. One of the Government's efforts Samarinda is realize the City Shady, Neat, Safe and Comfortable (trim), as well as the need to implement the control and prevention of beggars and homeless children who do activities begging in medians roads, traffic lights and bridges are impassable both pedestrian foot and passed by other public transport. Begging act in various ways to induce the mercy of others who do on the road,

Homeless children as a social problem, especially urban communities, in the view of experts and organizations and related departments do not yet have a common ground and a uniform definition for it. In Chapter I General Provisions Article 1 Regulation of Samarinda No. 16 of 2002 which was replaced by Regulation of Samarinda No. 7 of 2017, the street child is defined as a person or a human child with an age limit 19 years of age who carry out their activities in addition to the side-street and or in the public streets in the city of Samarinda with the purpose to ask for money either on its own, groups and or ordered others to any other person or any 
driver (driver) or passenger motor vehicles, which can disturb peace and order general.

The concept of homeless children as stipulated in the regulations also can be identified by the characteristics of the street children. Mulandar provide four traits inherent when a child is classified as street children:

1. Being in public places (streets, markets, shops, places of entertainment) for 324 hours a day.

2. Less educated (mostly dropout, few primary schooling).

3. Derived from the families can not afford (mostly urban, some are not obvious family).

4. Economic activity (doing work in the informal sector).

In addition to the inherent characteristic would be its existence, homeless children can also be divided into three groups: First, Children On The Street; ie children who have economic activities as child labor on the streets, but has a strong relationship with their parents. The function of homeless children in this category is to help strengthen their economic buffer for the load or the pressure of poverty that must be borne and can not be solved alone by his parents. Second, Children Of The Street; namely the children who participate fully in the streets, both socially and economically, some of them still have a relationship with their parents but the frequency is not stabilized. Many of them are children who for some reason, usually violent, run, or go home. Third, Children From Families Of The Street; namely the children who come from families that live on the streets, although these children have family ties are strong enough, but living them oscillate from one place to another with all the risks. ${ }^{1}$

The existence of urban homeless children will eventually become a city government problem when it is faced with the elimination of child labor and any activity that might interfere with the child's growth as a consequence of ratification of ILO Convention No. 138 with Law No.20 / 1999 on the minimum age of children allowed to work, as well as ILO Convention 182 by Law No.1 / 2000 on the elimination of child labor. Economic motive which is one reason why children should be homeless is inseparable from the existence of child labor itself.

City government's policy in dealing with the existence of homeless children will be key in attempts to limit or even eliminate homeless children themselves for the future of the nation. There are various types of commonly used policy model policy makers in addressing a public issue. ${ }^{2}$ see that the model policy (Policy Models) is a simple representation regarding selected aspects of a problem condition prepared for specific purposes. Policy model is a simplification of system problems (masses) to help reduce complexity and make it manageable by policy analysts. Some models are commonly used policies; descriptive model, normative model, the model of verbal, symbolic models, procedural models and models as a substitute and perspectives.

1 Bagong Suyanto, 2003, Data Collection from Social Issues (Street Children in Surabaya: Priority Issues and Management Program), Research Institute of the University of Airlangga, Surabaya, p. 8

2 William Dunn, 2000, Introduction to Public Policy Analysis, The Second Edition, Gadjah Mada University Press, Yogyakarta, p. 231 


\section{B. DISCUSSION}

\section{Factors That May Affect Government Efforts to Tackle Problems In City Street Children}

Lives of homeless children with a variety of characteristics is characteristic that distinguishes it from other communities. Negative image that has been attached to homeless children become the focus of attention of all the parties concerned to the efforts of development and cultivation of the street children. Work environment / association of homeless children away from their families and continue to deal with the rigors of life make them grow and develop in accordance with the demands of the environment. The condition also become an everyday sight on homeless children in the city of Samarinda.

Distribution of homeless children in the city of Samarinda centralized in urban centers such as red light intersection in the heart of the city (crossroad General Ahmad YaniCenderawasih, Crossroad Mall Lembuswana, Third intersection of Kusuma Negara, Juanda intersection and crossroad Agus Salim), center-traditional shopping center (morning market, Segiri market, Kedondong market), places of worship (mosque next feast, Islamic Center). Routines homeless children in public places are economically motivated. They fell to street for economic income or even just the mercy of the public places with donations perfunctory. Various methods are used to attract the attention of the users of public facilities such as; newspaper sellers, hawkers, shoeshine boys, street, your old beggar, and even begging conducted directly. Based on the interview with the Head of Services and Social Assistance found that: Characteristics of homeless children in Samarinda basically showed its own characteristics. It is intended that on the way to work on the streets can be identified based on their origin ie: those from Madura, Java, Buton, Banjar and Sulawesi (tribal settlers) generally work the streets as a beggar child, the old beggar, beggar disabled and singers, while they the population was born and live in New York City with his family (Banjar) usually work as newspaper sellers, hawkers and cleaner cars. Characteristics of homeless children in Samarinda basically showed its own characteristics. It is intended that on the way to work on the streets can be identified based on their origin ie: those from Madura, Java, Buton, Banjar and Sulawesi (tribal settlers) generally work the streets as a beggar child, the old beggar, beggar disabled and singers, while they the population was born and live in New York City with his family (Banjar) usually work as newspaper sellers, hawkers and cleaner cars. Characteristics of homeless children in Samarinda basically showed its own characteristics. It is intended that on the way to work on the streets can be identified based on their origin ie: those from Madura, Java, Buton, Banjar and Sulawesi (tribal settlers) generally work the streets as a beggar child, the old beggar, beggar disabled and singers, while they the population was born and live in New York City with his family (Banjar) usually work as newspaper sellers, hawkers and cleaner cars. ${ }^{3}$

The emergence of homeless children is closely related to the economic and social background of their 
families. Structural poverty experienced by families of homeless children is considered as the main drivers of the rise of street children. Difficult to meet the daily needs by the head of the family (both father and mother) impact on efforts to empower all family members to play an active role in meeting the needs of life. It is not just the mere fulfillment of the needs of food and clothing, but much of it associated with the need to exist in a wheel rigors of urban life. All family members have equal responsibility to jointly improve the economic status of families with productive activities in order to generate additional family income.

Conduct a study on children is very interesting, since the child is the successor to the ideals for progress of a nation. Within a child's own nature and special characteristics, namely physically and mentally not yet have the ability to stand on its own so that children in need of protection in order to ensure growth and development as a whole and harmonious life. ${ }^{4}$ Poverty factors as described more reason to factor structural poverty. This condition can be experienced by all citizens who are not able to follow directions and urban competitions with different dynamics. In addition to these factors other causes the emergence of homeless children in urban areas are: the mental attitude that does not support such a lazy attitude to work hard or the lack of proper implementation of the advice of parents will be the meaning of "filial". In this stage the child is seen as one source of

4 Ida Musofiana, 2017, Role of Integrated Service Center Chrysanthemum Semarang Central Java in Providing Legal Protection for Children Victims of Domestic Violence Value-Based Justice, Journal of Law Reform IV volume number 1 in 2017 PDIH Unissula, Semarang. family income, so that a child is considered to have the potential to generate financial resources in order to support their families.

City government's efforts in dealing with homeless children in the city of Samarinda have to deal with people with different environmental elements of the jib. Support legislation and policies of prevention and empowerment undertaken by the municipality still has to be dovetailed with the social conditions in this area. Various factors have been considered as a classic problem that gave rise to homeless children requires serious attention so that the effectiveness of the activities carried out by the city government can run as expected. Factors that could affect the city government's efforts in tackling the problems of homeless children include:

1. Social environmental factors.

The social environment is one aspect that can encourage a child to become street children. Matters related to the social environment are:

a. Homeless children who took to the streets for their family economic pressure, thus creating the parent told his son to take to the streets to seek additional family income.

b. Slum dwelling house made the children are not comfortable in the home so that slum housing to be one contributing factor to child down the road.

c. Lack of education of parents cause they do not know the role and function as a parent and also do not know the rights of the child. So that the exploitation of children may appear at any time, including by 
directing children to become street children.

d. The role of social institutions is not maximized role in encouraging community participation to address the problem of street children.

2. Culture Society.

The city government's efforts in tackling the problems of homeless children in the city of Samarinda should collide with a society that has been entrenched habits that willingness to give some money to the children in the streets. It distinguishes Samarinda with other regions do not lie in the mere willingness, but a nominal amount of money given to homeless children which is relatively higher compared to other regions. This condition then be the reason why children feel at home to stay and make a living on the streets

3. Migration factors.

The appeal to the people to seek a better livelihood in other areas caused migration to the quality of human resources are inadequate. The arrival of migrants in the city of Samarinda was not always as expected, the emergence of homeless children turned out to be the result of the migration. Several groups of families that fail to compete in the end thinking to maximize all the potential resources at their disposal, including by encouraging their children to become street children.

These three factors are becoming a reality that can not be avoided by the municipality when it will address the homeless children in the city of Samarinda. Various approaches implemented strategies need to be pursued so that the measures taken not only in children streets, but will involve all aspects underlying the emergence of street children.

\section{Legal Efforts Conducted by the Government of Samarinda's Homeless Children in Solving Problems As a fallout of Urban Development}

Legal remedy in preventing or dealing with homeless children in several cities experiencing problems from the aspect of the legislation in force. No or the unavailability of a legislation that regulates the coping mechanisms of homeless children and its implications become classic excuse when the local government will take care of the street children. Pattern owned approach is considered relatively less qualified when it did not receive support in the form of legislation that is clear. Child Protection Act No. 35 of 2014 on changes to Act number 23 of 2002 on the protection of children not specifically provide direction handling and overcoming problems faced by street children. As one of the city government's seriousness in addressing the problem of homeless children in the city, local governments together with the Regional Representatives Council (DPRD) of Samarinda made a rule about the control and prevention of homeless children contained in the Regional Regulation No. 16 of 2002 on Control and Prevention Beggars, homeless children and homeless in Samarinda City Region. With the legal protection has become a reference act for relevant agencies that directly deal with the street children. Samarinda City Regulation No. 16 of 2002 clearly provides for the rules 
on countermeasures, rehabilitation mechanisms or clear sanctions for those that resulted in the emergence of street children. With the regulation be a valuable asset to the Department of Social Welfare to establish an action plan in the context of prevention and control of street children. Besides the existence of regional Regulations also automatically create relevant agencies such as municipal police to play a role in the prevention and treatment of street children. Only Samarinda City Regulation No. 16 of 2002 is not too benefit, so that authorized Samarinda City Regulation No. 7 of 2017 results reexamination with the reality of current developments.

City government's policy in dealing with the existence of homeless children will be key in attempts to limit or even eliminate homeless children themselves for the future of the nation. There are various types of commonly used policy model policy makers in addressing a public issue. Dunn saw that the model policy (Policy Models) is a simple representation regarding selected aspects of a problem condition prepared for specific purposes. Policy model is a simplification of system problems (masses) to help reduce complexity and make it manageable by policy analysts. Some models are commonly used policies; descriptive model, normative model, the model of verbal, symbolic models, procedural models and models as a substitute and perspectives. Various efforts undertaken by the city government in coping with urban homeless children conducted with the involvement of all elements related to both government agencies, the International Labor Organization (ILO) as well as non-government community organization (NGO) that focuses on advocacy efforts and protection of child labor. Meanwhile Twikromo see that there are at least two approaches that are commonly used in tackling the problem of street children, namely: First, preventive Countermeasures. Usually taken formal situation, in this way tend to be implemented in the classroom with the number of participants is large enough, as a situation where the formal guidance, exercises and approaches may be held individually in the streets, and Second, repressive Countermeasures. Now organized and government agencies to reduce or prevent the spread of the influence of the problem of homeless children such as the raid. Represive prevention efforts are usually carried out by the municipality when looking at the activities of homeless children has been disturbing public urban areas.

City government's policy in dealing with homeless children in line with the mandate of Article 55 of Act No. 35 of 2014 on the protection of children include:

1. Central government and Local Government is obliged to keep the maintenance, care and social rehabilitation of abandoned children, both within the institution and outside the institution.

2. Implementation of maintenance referred to in paragraph (1) may be conducted by public institutions.

3. To carry out maintenance and care of abandoned children, government agencies and public institutions, as referred to paragraph (2), can be entered into a collaboration with the various parties concerned.

4. In the case of providing maintenance and care as referred to in paragraph 
(3) supervision carried out by the ministry that responsible government in the social sphere.

Efforts to reduce or even eliminate homeless children in the city of Samarinda as mandated by the Regional Regulation of Samarinda No. 16 of 2002 which has been replaced by Regulation of Samarinda No. 7 of 2017 provides maximum protection to the child no longer be the responsibility of the city government alone, but will involve all the stakeholders there. Clear conditions be important for the growth of the formation of homeless children is not dominated by a single factor, but there are three aspects that play a role in the formation of street children:

1. First, which includes the social environment; family environment (parents, siblings), coworkers, school environment, and relations with the public.

2. Second, cultural environment; Most families of homeless children is a family undercoat lived in slums, for those who are still living with their parents get the urge to sell so that they can help the economic daily situation.

3. Third, personal aspects include; their motivation to become street children, forms of life they lead, hopes and disappointments, aspirations and problems encountered.

The existence of regional regulation as the basis for the handling of homeless children in the city of Samarinda need to be implemented by all stakeholders. Implementation of policies meant to understand what happens after a program was formulated, and what the effects of that policy program. In addition, policy implementation is not only related to administrative problems, but also examine environmental factors that influence the policy implementation process. The issue of homeless children as an urban problems that arise in various dimensions of social life clearly can not be ignored. This corresponds to the position of homeless children who should receive the full protection of the family and the government has become a classic problem that must be faced by the government of Samarinda. Policy direction and approaches undertaken by the municipality in dealing with homeless children in the city is becoming an interest to be appointed in the scientific research topic. It is based on the consideration that as the Capital City of Samarinda in East Kalimantan region with per capita income is relatively high.

For the legal basis in the implementation of the Prevention and Control referred to, have established the Regional Regulation of Samarinda City No. 7 of 2017, Beggars are the people who carry out their activities by begging in public or on the road or at an intersection-intersection in various ways and reasons to expect mercy from others and may disrupt public order.

From the things that have been described above, these cases occur in the city of Samarinda, wherein the uneven development and economic growth. Development in the city of Samarinda is progressing so rapidly. Visible from several buildings, especially in terms of infrastructure, such as construction of bridges, construction of high-rise buildings such as for example Mall, and so on. As a result, not a few people from outside the city of Samarinda trying to seek his fortune and 
change their fate and hope they get better economy. In the end they already come to the city without the support with their education level is sufficient, expertise, and knowledge is still lacking. As a result of not having enough talent that they do not get a decent job. Even though so they remain living in the city, because they think making money in the city more easily than in the village. Thought patterns that have caused people ventured to come into town despite having no provision of expertise. If this is allowed to continuously be able causing widespread social problems in the city of Samarinda, for example, is the case in the city of Samarinda is the case of street children. In 2011 the homeless children who netted in the raids amounted to 233 children, and then in 2012 dropped to 197 children and 187 children in 2013. And in 2014 decreases with the number of 63 people. But in 2015 the number of homeless children has increased to 86 children. After demolition, the streets are not really apart from the name of the street children. Samarinda City Regulation No. 7 of 2017 Control and Prevention of Beggars, homeless children and homeless until today there are still homeless children who roam the streets.

UNICEF study on children who are categorized as children of the street, indicates that the motivation they live on the streets is not just due to the insistence of the economic needs of the household, but also because of the violence and rift domestic life her parents. For these children, although the actual street life no less loud, but nevertheless judged more provide alternative than to live in a family filled with violence they can not avoid.
Although not always the case, but often found that the background of the children chose to live on the streets is due to cases of child abuse (the wrong actions in children).

Causes of the emergence of homeless children in the community are as follows:

1. Social Environment Against Children,

Understanding social environment are all external factors affecting the development of the human person, who comes from outside the self. Conceptually, the social environment includes elements of which are:

2. social process

Social processes are the core dynamics of the social environment. The core is a social process of social interaction, which is a process of mutual relations between individuals, between groups and between individuals in a group. Social process itself encompasses the relationship between the various areas of human life, such as for example, the political, economic, social, cultural, military-security, and law.

3. social structure

The social structure became the foundation of social environment, thus covering the social aspects of the subject. Aspects of it, which is an abstraction of the social process, is a social group, culture (which is discussed separately), social institutions, social stratification, power and authority.

Social changes (which sometimes are part of social processes, the element is separated from the social process that is meant to indicate that social change is a change in the social structure). 


\section{CONCLUSION}

Based on the results of Control and Development Study on Homeless children in Samarinda, then a number of conclusions:

1. Factors that could affect the city government's efforts in tackling the problems of homeless children consists of social environmental factors, Culture Society, Migration Factor These three factors are becoming a reality that can not be avoided by the municipality when it will address the homeless children in the city of Samarinda. Various approaches implemented strategies need to be pursued so that the measures taken not only in children streets, but will involve all aspects underlying the emergence of street children

2. Legal efforts by the city of Samarinda in addressing the problems of homeless children as the impact of urban development in Samarinda by reconstructing Regulation of Samarinda City No. 16 of 2002 is not too benefit by improving regulation of Samarinda No. 7 of 2017 which is implemented with the reality of current developments this.

\section{BIBLIOGRAPHY}

Bagong Suyanto, 2003, Data Collection Social Issues (Homeless children in Surabaya: Priority Issues and Management Program), Research Institute of the University of Airlangga, Surabaya.

Bagong Suyanto and Hariadi, Sri Sanituti, 2002, Crisis and Child Abuse, Sociological Studies of Children's Rights Violations case and Children in need of Special Protection (Child in Need of Special Protection), Airlangga Univercity Press, Surabaya.

Anonymous, 2008, Act No. 23 of 2002 on the Protection of Children, Asa Mandiri, Jakarta.

A.Widjaja, 1989, Homeless Children, A Coordinating Body of Jakarta Welfare and Department of Psychology, University of Indonesia, Jakarta.

Deddy Mulyana 2004, Qualitative Research Methodology, New Paradigm of Communication Sciences and other Social Sciences, PT.Remaja Rosdakarya, Bandung.

Ida Musofiana, 2017, The Role of Integrated Service Centers Chrysanthemum Semarang, Central Java in Providing Legal Protection for Children Victims of Domestic Violence Value-Based Justice, Journal of Law Reform IV volume number 1 in 2017 PDIH Unissula, Semarang.

Soenarko, 2005, the Public Policy: Understanding Principles for Understanding and Analysis of Government Policy, Airlangga University Press, Surabaya.

William Dunn, 2000, Introduction to Public Policy Analysis. The second edition, Gadjah Mada University Press, Yogyakarta 
Act No. 1 of 2000 on the Ratification of ILO Convention 182 omor conserning the Prohibiton annealing intermedite Action for the Elimimination of the worst forms of Child Labor.

Act No. 35 of 2014 on the Amendment of Act 23 of 2002 on Child Protection. Samarinda City Regulation No. 16 of 2002 on Control and Prevention Beggars, Homeless children and Homeless In Samarinda City Region, Samarinda City Regional Gazette No. 162002 Series D No. 10. Samarinda.

Samarinda City Regulation No. 7 of 2017 On Control and Prevention Beggars, Homeless Children and Homeless In Samarinda. 